\title{
The Golden Rule: Interfaith peacemaking and the Charter for Compassion
}

In 2008 the organisers of Technology, Entertainment and Design (TED) Talks honoured religious historian Karen Armstrong with the opportunity to change the world through launching her vision in a TED Talk. Armstrong's vison was for a (re)turn to compassion as the guiding principle underpinning the global order. Working with leading thinkers within the three Abrahamic faiths, Armstrong launched the 'Charter for Compassion', envisioning a world where 'everyone is committed to living by the principle of compassion'. The Charter has been signed by over two million people from around the world and partnered with hundreds of interfaith organisations and cities seeking to put into practice the 'Golden Rule', common to the main faith traditions, of doing unto others as you would be done by.

While few would argue that compassion is sorely needed in contemporary society, this article explores the efficacy of the Charter, setting it in the context of a post-secular international society, in which religious and interreligious initiatives emerge as primary, rather than peripheral, actors in developing sustainable peace making through bottom up approaches. I argue that the Charter's claim that 'any interpretation of scripture that breeds violence, hatred or disdain is illegitimate' is a flawed but wellintentioned construction, which can encourage meaningful inter-religious dialogue and peace building efforts. The Charter itself emerges as a rhetorical device encouraging compassion rather than a practical tool to mobilise and facilitate peacemaking.

This article begins by conceptualising the increasing salience of a post-secular international environment for secular audiences desirous of peaceful resolution of conflict. Second, the role of faithbased diplomacy in engaging religious actors in peacemaking is considered as a precursor to, thirdly, examining Armstrong's advocacy of the Golden Rule and religious peacemaking. Fourth, this article explores peace initiatives inspired by signatories of the Charter for Compassion before concluding that Armstrong's initiative remains largely aspirational, affirming principles of compassion rather than developing practical peacemaking efforts based on the Charter.

\section{A post-secular world?}

The concept of post-secularity has become familiar, albeit contested, within western political thought, and belatedly in international relations as scholars, public intellectuals and norm entrepreneurs have sought to account for the persistence or resurgence of religion within a globalised and modernising world. Jürgen Habermas' defection to post-secularism (a highly contested term which assumes that a largely Christian West became an ostensibly secular polity, after the Treaty of Westphalia, and increasingly so following the American Declaration of Independence and French Revolution, and has recently re-engaged with religion) paved the way for a re-evaluation of the relationship between immanence and transcendence and the public and private sphere (Habermas 2007, 2008).

Habermas, whose approach we examine later, is not alone in challenging a secularist orthodoxy that over the course of the twentieth century largely disregarded religion or at least sought to confine it to the private sphere. Talad Asad (2003), William Connolly (1999), John Milbank (2006) and Charles Taylor (2007) have all made significant interventions into understandings and contestation of what Taylor later describes as 'A Secular Age'. Jose Casanova (1994) challenged the popular responses to secular orthodoxy and offers revisions to the secularist paradigm. But how did we arrive here? And where does the concept of post-secularity take us in terms of the capacity of religious actors to enter the public sphere to contribute to peacemaking?

The roots of a secular international relations are typically traced back to the Peace of Ausburg (1555) and the subsequent Treaty of Westphalia (1648), bringing to an end the Thirty Years War. The treaty enshrined the principle of cuius regio eius religio, subordinating religion to the predisposition of the ruler and reinforcing sovereignty by proscribing the interference of states in the religious practices pursued by another state. On this foundation, a realist international order emerged based on pluralism, with states as the principle actors and religion restricted to the private sphere (Thomas 2005 54-55). Religion was perceived as a (or the) problem to be protected from. Religion's propensity for domestic disputes and international warfare require the liberal state to privatise religion through a process of secularisation, whereby the public square becomes a place for rational discourse from which the religious are excluded or rather constrained to translate their contribution into secular language before such a contribution is legitimated (Rawls 1997: 783; Habermas 2010: 25-6). 
Secularisation theory portrays religion as pre-modern based on irrationality and superstition, which has relevance only to individuals at the private level. As society becomes more modern the influence of religion and religious observance will decline (Berger 1967; Bruce 2002; Thomas 2005: 52; Norris and Inglehart 2011). The decline of religion was presented as not only empirically inevitable but also desirable in pursuit of a more pacific world. Secularisation theory is based on at least three foundational myths. Namely that it constructs a social world in which modernisation and rationality are essential and desirable and that religion is antithetical and an obstacle to human progress (Bellah 1991). That religion is inherently prone to violence and can only be subdued by the liberal nation-state (Cavanaugh 2009: 4). Third, that religion is constructed as a set of individual beliefs and practices that can and must be set aside before entering the public square, which is continually being redefined to determine the limits of religious participation in society (Asad 2003: 210).

Charles Taylor observes that secularism distinguishes between church and state, separates church and state, and sidelines religion from the state and public life (Taylor 2007, 2009). Erin Wilson meanwhile, identifies the forces of secularisation portraying religion as backward in contrast to secularism as 'natural and universal' (Wilson 2012: 43). This division of religion and the secular is a social construction and overlooks the reality that religion and politics have always coexisted and been mutually constitutive (Agensky 2017; Hurd 2008; Thomas 2014; Walzer 2007, 147-67). The dominance of secularism within the western academy and polity has established the narrative of religion being a primary source of dispute and violence leading to warfare. This has effectively proscribed the willingness of secular governments, until comparatively recently, to engage with religious actors in peacemaking activities.

The difficulty for secularisation theory is that despite, or possibly because of, modernisation and globalisation, religious belief and adherence has proved remarkably resilient. This has led key proponents of the theory, including Peter Berger, to recant, acknowledging a religious resurgence (Berger 1979). Habermas, while still wedded to the unfinished Enlightenment project, has sought to accommodate religious actors within a liberal order, in accordance with his theory of communicative action and discourse ethics (Ott 2015). While insisting that before 'the potential truth contents of religious utterances' are shared in the public sphere they 'must be translated into a generally accessible language before they can find their way onto the agendas of parliaments, courts, or administrative bodies and influence their decisions' (Habermas 2010: 25-26). Religious and non-religious actors should show mutual respect and reciprocal recognition; while they are able to use their religious language they must rely on the secular state to translate it for them (Habermas 2004, 2006). On the basis of reciprocity, secular citizens must not dismiss or denigrate religious contributions to public discourse and should assume the genuineness of religious citizens in their belief (Habermas 2010).

While Habermas opens the possibility of religious actors being welcomed as equal citizens, able to contribute in the public square without having to put aside their religious identity, his vison of the postsecular remains locked within a secular mind set. Adrian Pabst identifies Habermas' conversion as only partial, making no allowance for religious truth claims in the public sphere. An asymmetric burden falls on religious actors, having to translate, or have translated, their discourse with a presumption of irrationality while secular actors are attributed with rational thinking (Cerella 2012; Pabst 2012). Ott (2015) accuses Habermas of co-opting religion to the Enlightenment project, while 'the socio-ethical revolutionary substance of religion is pushed to the margins' (Ott 2015: 30). Fred Dallmayr (2012) is critical of the arrogance of assuming that it is only religious language which needs translating given the impenetrability of many rationalist texts, we might add including Habermas' own work.

Post-secularity has significance in a western context and marks a growing recognition in the academy and among policy makers that religious actors should be able to operate in the public sphere and, indeed, can be useful in seeking to address societal and international problems. Rather than perceiving religious actors as either a cause of, or encourager, of violence or irrationality in the public sphere the capacity of religious actors to ameliorate violence and to engage legitimately as religious actors in political processes has become acceptable to policy makers, despite opposition from secularists. The turn to post secularity opens up opportunities for faith-based organisations, including The Charter for Compassion International (CfCI), to call on faith groups and individuals to campaign in the public sphere around shared values, and to appeal directly to individuals and policy makers on the basis of shared values across faiths. This enables the organisation to be able to engage in political processes, education, and 
health, and peace-making initiatives with partners around the world without being excluded or marginalised by policy makers because of their interfaith position.

\section{Faith-based diplomacy}

The willingness of policy makers and the academy to consider the involvement of faith-based actors in the public sphere opens the possibilities for umbrella organisations such as the CfCI, which has emerged from an online petition into developing a network of partner organisations, to be involved with secular bodies, including governments, in diplomacy and peacemaking. Such a move has been a long process and owes much to the work of Douglas Johnston $(1994,2003,2011)$, Brian Cox $(2003,2016)$ and Daniel Philpott (2003). Beginning with the seminal edited volume, Religion the Missing Dimension of Statecraft, Johnston and his fellow contributors made the case for an increased involvement of religious actors in diplomacy in a world where religion remained a significant part of culture and identity (Johnston and Sampson 1994). Faith-based diplomacy, it is argued, would provide an extra dimension to the efficacy of foreign policy with new diplomats informed by faith values and able to relate to a world where those values resonate (Johnston 2003). While faith-based diplomacy lends itself to statebased diplomacy it also operates at the sub-state level, with engagement and diplomacy across faith groups.

'Faith-based diplomacy is oriented towards the divine. That is its most central and distinctive principle. Its motivating vision of politics, its assumptions about human nature and the political order, and the norms that govern its conduct all arise from an understanding of the nature and activity of the divine' (Cox and Philpott 2003: 32).

For Cox and Philpott, the extra dimension those faith-based diplomats are able to offer, that their secular counterparts may not, involves their conscious dependence on spiritual principles and resources. They are able to operate with a spiritual authority, understanding and respecting other faith traditions. They have an awareness of what is irreconcilable in religious traditions and, perhaps most importantly, they possess a deep sense of divine calling which equips them to persevere against overwhelming odds (Johnston and Cox 2003: 16-17). Faith-based diplomats are able to call on spiritual resources that their secular counterparts cannot. Resources which resonate with other faith actors including prayer, fasting, reading of sacred texts, exercising rites of healing, and the performance of rituals. The recognition of sinfulness and wrongdoing is a crucial part in the process of acknowledging evil and hurt and enabling a genuine process of apology, forgiveness and reconciliation to occur (Cox and Philpott 2003; Cox 2015). Such resources are most useful, possibly only useful, where the participants in conflictual situations have a shared appreciation of religious experience and faith tradition, even where religious traditions are diametrically opposed.

Faith-based diplomacy, according to proponents, is most effective where a religious dimension is involved in the dispute and is predicated on actors involved respecting religious differences and not seeking to proselytise or denigrate the others beliefs (Johnston and Cox 2003; Appleby 2003). Advocates argue that religion should be a 'genuine' factor in the conflict rather than simply being a rhetorical device to mobilise support (Johnston and Cox 2003: 19-22; Appleby 2003: 238-430). Although how to differentiate between what constitutes a religious factor and the use of religion to mobilise support, and who gets to decide, is never clearly established, indeed how 'genuineness' is defined, and by whom, is problematic. There might also be a role for faith-based diplomacy where religion plays no part in the dispute and yet faith-based organisations are seen by their proponents as sincere and neutral. The role of the Holy See (Troy 2017), Society of Friends (Ceadal 2003) and the significant role of the St. Egidio community (Haynes 2009) in brokering peace in the civil war in Mozambique are prime examples for faith-based diplomacy advocates of religious actors being able to mediate in non-religious conflict (Johnston and Cox 2003: 19-22; Appleby 2003: 238-43; Smock. 2006: 35-39).

Faith-based diplomacy received support from former president Jimmy Carter, who wrote the foreword for Johnston and Sampson's book. On leaving office, recognising the importance of religious literacy for US diplomats, former Secretary of State Madeleine Albright noted: 
'They should develop the ability to recognize where and how religious beliefs contribute to conflicts and when religious principles might be invoked to ease strife. They should also reorient our foreign policy institutions to take fully into account the immense power of religion to influence how people think, feel, and act' (Albright 2007: 66-7).

Faith--based diplomacy advocates and sympathetic policy makers' desire for state institutions to become religiously literate and to co-opt religious actors, in pursuit of foreign policy objectives, and the 'people-based' initiatives of the CfCI are not mutually exclusive. Greater awareness of the value of religious engagement by the state legitimises the role of faith-based actors in the public sphere and increases the receptivity of the state to interventions by faith based groups and individuals. The George W. Bush and Obama administrations encouraged increased religious participation domestically and internationally to deliver assistance programmes through the establishment of the White House Office of Faith-Based Initiatives and later White House Office of Faith-Based and Neighborhood Partnerships. Albright's advice has been heeded in the field of diplomacy with US policy makers establishing a Center for World Religions, housed at the US Army Chaplains School, and 'culture centers of excellence' opened at US Central Command and Air (Force) University (Paterson 2011: 99). The amended 1998 International Religious Freedom Act now empowers an Ambassador at Large for International Religious Freedom to coordinate religious freedom policies across all US programmes and activities and to participate in interagency processes where religious freedom can advance US national interests. All Foreign Service officers, out-going deputy chiefs of mission and ambassadors on religious freedom receive training in religious literacy. In 2013 an Office of Religion and Global Affairs was introduced to advise and assist the State Department on all matters pertaining to faith and to train State Department officials. The appointment of a Special Envoy to Monitor and Combat Anti-Semitism, the Special Representative to Muslim Communities, and the Special Envoy to the Organization of Islamic Cooperation, reflects a deeper commitment to religious engagement.

The US foreign policy establishment, under the Obama administration, appeared to have taken on board the value of faith-based diplomacy (Birdsall 2016). Secretary of State John Kerry's launching of the Office of Faith Based and Community Initiatives at the State Department in August 2013 affirmed the principles of faith-based diplomacy and his intention to work with faith communities around the world:

'It's mission is as clear as it is compelling: It is to engage more closely with faith communities around the world, with the belief that we need to partner with them to solve global challenges, and there is an enormous partnership, I believe, there for the asking' (Kerry 2013).

For US policy makers, engaging with religious and interreligious groups provides an opportunity to harness soft power and leverage US influence and assistance through the legitimacy conferred within societies where religious faith and organizations command popular local support and trust. Religion in this scenario becomes another tool in the US diplomatic toolbox to be used when it advances US foreign policy interests to do so. In co-opting religious actors, the burden is transferred from government agencies to the religious subcontractors. Whatever the motivations governing such engagement, such initiatives reflect recognition of the importance of the role of religion and religious actors in contemporary politics. In such an environment the Charter for Compassion is indicative of a trend towards encouraging and partnering with religious actors to meet global challenges, including peacemaking.

Other ostensibly secular countries have also shown a willingness to engage with religion in their approaches to foreign policy including the United Kingdom, Canada and France (Annicchino 2014; Mandaville and Silvestri 2015), Italy (Petito and Thomas 2015) and post-communist countries (Simons and Westerlund 2016). The Woolf Institute based in Cambridge, UK has delivered training courses on religion, policy and diplomacy to the Foreign and Commonwealth Office, Ministry of Defence and the European External Action Force since 2013.

The embrace of religion, however, remains contested with Mandaville and Silvestri (2015) suggesting a continued ambivalence and resistance to engaging with religious actors. In the US context, confusion 
over the implications of the First Amendment leads to uncertainty about engaging with religious actors, and the risk averse nature of officials, erring on the side of caution, limits the effectiveness of such strategies. Training courses tend to be voluntary and in consequence are poorly supported, attended by the usual suspects rather than those most in need of religious literacy training. The turnover of officials on two to three year postings also creates difficulties in establishing meaningful relationships and trust over time (Mandaville and Silvestri 2015). Under the Trump administration the commitment to religious engagement has receded with key posts, including the Special Representative for Religion in Global Affairs, unfilled (Casey 2017).

Despite problems with top down approaches to faith-based diplomacy, bottom up approaches continue, encouraged by an environment in which religion is no longer regarded as peripheral by Western audiences in government and the academy. The Charter for Compassion, embraced largely, but not exclusively, by western audiences places religious faith at the centre of its approach to building a more compassionate (and peaceful) world by identifying religion as a source of peace rather than violence.

\section{The Golden Rule and Religious peacemaking}

Karen Armstrong puts great store by peaceful interpretation of scriptures and religious tradition. In the Charter for Compassion, devised with input from leading theologians and religious leaders representing different faiths, she urges people:

'To restore compassion to the centre of morality and religion - to return to the ancient principle that any interpretation of scripture that breeds violence, hatred or disdain is illegitimate - to ensure that youth are given accurate and respectful information about other traditions, religions and cultures - to encourage a positive appreciation of cultural and religious diversity - to cultivate an informed empathy with the suffering of all human beings - even those regarded as enemies' (Charter for Compassion 2009).

While acknowledging violence committed in the name of religion, Armstrong is eager to acquit 'religion' (as set of beliefs, identity, and people operating within a frame of meaning connected to it) of blame for that violence. Armstrong accuses modern secular society of making religion its scapegoat (Armstrong 2015: 1). The true nature of religion, for her, is to be seen in the proposition that the Golden Rule lies at the heart of all the world's major religions. Compassion for the self and others are seen as essential building blocks to a more peaceful world. This compassion for self and others is a component of religious teaching but places the primary responsibility on the individual to live out a compassionate life and to be the change they wish to see in the world (Armstrong 2011). For Armstrong, the referent object in international affairs is the human and the individual's capacity to reach across faiths and communities to become an instrument of change. While not discounting the efficacy of faith-based diplomacy and the benefits of religious literacy and engagement for policy makers, it is the individual who ultimately makes the difference, one person at a time. This distinctive bottom-up approach calls for a change in thinking by placing the onus on the individual and their interaction to achieve common objectives. Power shifts from the state, or international system, to the human to live out the example set by the Golden Rule and so effect change in society and attitudes towards the self and others.

Many faith traditions each have versions of The Golden Rule, beginning with the sayings of Confucius who described shu or 'consideration' as his key teaching, holding all others together. Shu also refers to 'likening to oneself', the principle of empathy, as is essential in to peacemaking (Armstrong 2011: 6). Confucius urged his followers to: 'Never do to others what you would not like them to do to you' (Analects 15: 23). Within the Christian tradition, Jesus commanded his disciples to 'Do to others as you would have them do to you' (Matthew 7:12). Muhammad similarly insisted that we should: 'Wish for others what you wish for yourself' (Hadith 13, Nawawi). In the Jewish tradition the Rabbi Hillel was asked by a gentile to explain the Torah while he stood on one foot, his reply invoked the Golden Rule: 'What is hateful to you, do not do to your fellow: this is the whole Torah; the rest is the explanation; go and learn' (Talmud, Shabbat 31a). The Buddha advised people to: 'Treat not others in ways, you yourself would find hurtful' (Udana-Varga 5:18). Hindus are also advised: 'Do not do to others what would cause pain if done to you' (Mahabharata 5: 1517). 
This shared starting point of the Golden Rule provides a valuable starting point for inter and intra faith dialogue, if the participants all share such a view, but proves to be far more difficult to achieve for 'secular' diplomats representing 'secular' countries, even where they may personally share the same compassion outlook. The world, although it may not be secular anymore, is still not discovering the power of religion to solve problems. The lived experience of religious communities reflects that violence remains a reality in everyday life and people of faith are not immune to the violence that permeates society. Violence in the name of religion existed before the sacred texts were written and the texts themselves are replete with tales of sacred and profane violence. Why should readers of sacred texts accept Armstrong's insistence that a reading of such texts as a vindication or exhortation to violence should be seen as illegitimate? This is a problem Islamic scholar Muhammad Tahir-ul-Qadri has wrestled with in connection with Al Qaeda and ISIS claims to be acting in the name of Islam:

'They and their cohorts practice Islamic rituals, perform acts of worship and display the outward forms of religiosity encapsulated in the Shariah (Islamic Sacred Law). This has put not only the common Muslims into a dilemma, but also a significant number of religious scholars and intellectuals. They are perturbed and curious to know truly the real Islamic stance on the methods these individuals and groups have adopted to wreak their havoc' (Tahir-Ul-Qadri 2010: 3-4).

For Muhammad Tahir-Ul-Qadri (2010), the answer is to be found from the starting point that Islam, as revealed in the Qur'an and Hadith (the record of the words, actions and approvals of Muhammad) is a religion of peace and any interpretation which deviates from this is wrong. Using the fatwas of Islamic scholars over generations, Tahir-Ul-Qadri presents Islam as 'peace incarnate. It encourages humankind to be moderate, peaceful, kind, balanced, tolerant, patient and forbearing' (Tahir-Ul-Qadri 2010: 21). Critiques of Islam often see things very differently. The dualist thinking of religion as the cause or solution to violence is fundamentally flawed, in that such views essentialise multifaceted and multidimensional religious teaching and lived experience that requires nuance and context. A common refrain of Islam as a religion of peace amongst Muslims today, is also one other religions could make; such a claim, however, is essentialising and misleading in the same way as describing any religion as one of violence. For Christian scholars, the peaceful nature of Christianity or commitment to nonviolence is proclaimed through the historic peace churches including Mennonites, Anabaptists, Quakers (Society of Friends), and Church of the Brethren (Yoder 1983; 1994) and increasingly by the Roman Catholic Church. And yet the pacifism of the Early Church and the peace churches stand out as exceptional across church history.

Over the course of the twentieth century the Catholic Church demonstrated a retreat from just war theory, the idea propagated, among others, by Augustine, Aquinas and Hugo Grotius, that war could be justified through adhering to a set of conditions governing how war could be entered into, and by whom, and how it was to be conducted once embarked upon in order to be considered 'just'. Pope Leo XIII's issued the encyclical Rerum Novarum in 1891 that peace should be based on love and justice rather than military alliances and weapons. Pope John XXXIII's encyclical Pacem in Terris in 1963, Vatican II and Paul Vi's Nostra Aetate (Declaration on the Relationship of the Church to Non-Christian Religions, 1965) and the legacy of Pope John Paul II (1978-2005) emphasising non-violence and peace, international law and institutions, and interfaith dialogue to overcome violence and religious conflict (Christiansen 2006: 22). Pope Francis describes an authentic Christianity as one characterised by peace and nonviolence:

'But Christ's message in this regard offers a radically positive approach. He unfailingly preached God's unconditional love, which welcomes and forgives. He taught his disciples to love their enemies (cf. Mt 5:44) and to turn the other cheek (cf. Mt 5:39) ... Jesus marked out the path of nonviolence. He walked that path to the very end, to the cross, whereby he became our peace and put an end to hostility (cf. Eph 2:14-16). Whoever accepts the Good News of Jesus is able to acknowledge the violence within and be healed by God's mercy, becoming in turn an instrument of reconciliation' (Francis 2017). 
The Hebrew Bible surely ranks as one of the most violent religious texts ever written and yet even here, as Rabbi Jonathon Sachs reminds us, the rabbinical tradition explicitly rejects literalism and develops traditions of interpretation (Sacks 2015: 208). In this tradition, violence is ameliorated by God's true purpose of drawing humanity closer to God and one another. Within Jainism and Buddhism the tradition of ahisma, or non-harm, with the rejection of killing and the giving of oneself without expecting any reward is an essential component of life's journey (Cortright 2008: 186). In such a selective reading of sacred scripture based on interpretation, then, advocates of compassion, non-violence and peace have sought to construct a benign view of religion and open the way for faith-based diplomacy and peacemaking as a solution to rather than a cause of violence. In this interpretive tradition Armstrong is able to posit the individual's application of the Golden Rule as having the potential to transform society and the propensity towards violence one person at a time.

\section{Charter for Compassion and peace initiatives}

The Charter for Compassion starts from the standpoint of recognising that we live in a violent world and that religion has been mobilised for the purpose of terrorism, wars and violence that directly impacts on human insecurity. For Armstrong, and signatories to the Charter, religious involvement in violence is based on a misreading and misapplication of sacred texts which should be read as an encouragement to compassion, tolerance, and mutual understanding. The Charter focusses on reprioritising lives by focussing on individual compassion for others which signatories believe will lead to compassionate action. Peacemaking, religious tolerance and inter-faith understanding are part of the Charter's mission but Armstrong's objective is far more ambitious. She has sought to involve people across the world in working towards a shared compassion in tackling the UN Sustainable Development Goals. The intention is to transcend religious, ideological, and national differences and has received support from religious leaders across the world including the Dalai Lama, Archbishop Desmond Tutu and Rabbi David Saperstein.

A Council of Conscience, consisting of religious leaders and thinkers from different faith traditions, considered online suggestions from over 150,000 individual contributors to incorporate in the final version of the Charter for Compassion in 2009. Individual, organisations, and even cities have responded to the invitation to partner with CfCI in around fifty countries on five continents, although notable absentees include Russia, China, Japan, Israel, Saudi Arabia and Iran. Over 70 individual cities have partnered with the Charter, with a plan to work towards specific goals, but fifty of those are in the United States, reflecting a western centricity the founders were eager to avoid.

The Charter seeks to transform international and domestic politics by the compassion inherent within the religious traditions of all main faiths. In so doing it follows in a tradition of faith and interfaith initiatives designed to embrace the best aspects of what religions and cultures share in common including The Dialogue among Civilisations (1998), the Amman Message (2004), A Common Word between Us (2007), and the Marrakesh Declaration (2016). The Charter asks signatories to acknowledge their own wrongdoing and to dethrone the self in order to fully consider the other. Signatories commit to alleviate suffering, and to 'honour the inviolable sanctity of every single human being, treating everybody, without exception, with absolute justice, equity and respect'. They agree to 'refrain consistently and empathically from inflicting pain' and to 'encourage a positive appreciation of cultural and religious diversity' (Charter for Compassion 2009). Armstrong and her many co-authors are calling for a fundamental reappraisal of personal priorities and commitment to being the change we desire in the world:

'We urgently need to make compassion a clear, luminous and dynamic force in our polarized world. Rooted in a principled determination to transcend selfishness, compassion can break down political, dogmatic, ideological and religious boundaries' (Charter for Compassion 2009).

Armstrong seeks to move beyond rhetoric of compassion to provide practical exercises to develop compassion in individuals, organisations and communities. This is accessible by those engaged in faithbased diplomacy in foreign affairs departments and the tools and resource provided could be usefully deployed to increase religious literacy and develop a culture of compassion within individuals and the 
bureaucratic and organisations structure of those departments. Just as alcoholics are weaned from their alcohol dependency through involvement with Alcoholics Anonymous, so Armstrong has developed a Twelve Step Programme to a compassionate life, weaning the reader and participant from the selfcentred and intolerant life which leads to mistrust and potentially violence. The Twelve Steps begin (1) learning all about compassion before (2) starting to examine our world. Before we can (3) be compassionate towards others we need to develop compassion for ourselves. This will lead then to (4) empathy for others. Mindfulness (5) is necessary to (6) take action and (7) to reflect on our own lack of knowledge of the other and to prepare the way for abandoning our preconceived ideas. (8) Challenges us to think about how we should speak to one another before (9) exhorting us to have concern for everybody. (10) Is acquiring knowledge, which leads to (11) recognition of our self and the other. The prior steps cannot be circumvented and are necessary to reach the ultimate goal of loving our enemies (Armstrong 2011).

The Charter for Compassion is linked to achieving the United Nations Sustainable Development Goals. Goal 16 of which is 'dedicated to the promotion of peaceful and inclusive societies for sustainable development, the provision of access to justice for all, and building effective, accountable institutions at all levels' (Charter for Compassion 2009). The Charter has become a vehicle for bringing peace and non-violent organizations together seeking to conceive of and work to create a more compassionate world.

In Karachi, Pakistan, Charter for Compassion Pakistan, led by Zareen Qureshi, and funded by CfCI and their own fund raising efforts, formed a Compassionate Schools Network, initially working with 76 schools in the heavily populated city. The project is designed to reduce terrorism, gang violence and violence against women by creating a supplementary educational curriculum to teach empathy, courage, gratitude and tolerance through school lessons, art and sports. The project began in 2015 represents a ten-year commitment to train teachers and students in compassion, aiming to reach five thousand schools and two million children by the end of 2018 (Rupert 2015). Pakistan's state educational system has been in disarray with a narrow and has been criticised for an intolerant Islamic curriculum promoting opposition to India and learning by rote with little opportunity for questioning. Such narrowness is accused of encouraging radicalisation, potentially leading to terrorism (Afzal 2015). The project, supported by the United States Institute of Peace, has developed school libraries, and sought to tackle gang warfare in neighbouring Lyari Town through school and cricket outreach programmes working with school children to consider compassionate alternatives to gang violence and terrorism. The project is a long-term initiative which is claims positive outcomes in tackling long standing societal problems, and violence, through developing compassion in the next generation (Rupert 2015).

The project is one of a number of such initiatives in Pakistan carried out by faith-based actors largely working independently of one another. Muslim majority countries often seem to be the testing ground for such initiatives, which may be because of the perceived, and actual, instability and violence within such societies, and a combination of Western-based organisations believing they can make a difference and local groups seeking outside assistance in trying to solve difficult local problems, through the provision of extra resource. Charter for Compassion Pakistan is a local initiative by people from Karachi, inspired by Armstrong's vision:

'Pakistan is taking a leadership role in integrating the charter into civic life. this is a country right on the edge of the main conflicts that could fill our world - the whole world could implode because of what happens in Pakistan. It's got Afghanistan and Iran next door, it's a nuclear power, and it's had conflict with India since its inception. This is a really explosive situation. And yet the enthusiasm for the charter has been astonishing. I was there in 2011 for the launching of the charter, speaking three times a day, with thousands of people showing up each time' (Armstrong 2012).

As people commit to live compassionately individually, in families, schools, universities, businesses, the arts and culture, in relation to the environment, political systems and religious institutions then, CfCI claims, one by one lives have the potential to be transformed. The organisation encourages those whose lives have been touched by compassion to post videos on YouTube, Facebook and other social media testifying to how their lives have been transformed through applied compassion. Partners are able to access resources including peace newsletters, reports, and articles on peace, poems, art and 
music and connect with other partners. Organisations become partners by signing up to the Charter and asking to partner with the organisation based on shared objectives. CfCI facilitates connections between likeminded individuals, and organisations rather than organising such groups believing that such relationships and groups grow organically. There are around two hundred partners for peace, with half being situated in the United States, about forty in Europe, and a scattering of organizations in Canada, Mexico, Israel, Asia Pacific, South Asia and sub Saharan Africa. So far few Muslim peace organizations are represented and only two Arab countries are represented in Egypt and the Palestinian West Bank. Although the organization courts people of faith from around the world, inspired by Karen Armstrong's vision, the structure, marketing and approach is thoroughly Western. Although Armstrong herself is British, traction for the Charter is driven by the United States and US partner organisations. The Charter was drawn up by representatives of many different faith traditions and yet the impetus is overwhelmingly Western and as such has limited appeal where association with Western organisations is antithetical to grassroots, bottom up approaches.

Peace and non-violent organizations partnering with $\mathrm{CfCI}$ are engaged in peace and conflict resolution, advocacy, education, interfaith and inter community engagement, and training across war zones and areas of conflict. These include 'Beyond Words', a women's peace initiative working with Jewish and Palestinian women in Israel based in Kfar Vradim, 'Interfaith Peacebuilding Initiative' in Addis Abba, Ethiopia, and 'The Center for Peacebuilding' from Bosnia and Herzegovina. Many of these are well-established organizations which have been engaged in peace and conflict resolution and intercommunal engagement for many years. Few mention their involvement with Charter for Compassion or link to CfCI webpages, indicating a loose affiliation, or the relative unimportance of the relationship, rather than a close working partnership. This undermines the significance of the organisation and the difficulties experienced in moving from an inspiring idea, to a movement and to a global organisation, sufficiently resourced to make association meaningful for partner organisations. Originally funded by Armstrong's TED award CfCI the organisation is reliant on self-funding from supporters. In order to generate maximum interest and engagement with the vison it has spread its resources thinly and while effective in producing online resources for supporters and partners through its paid staff and interns is reliant on grassroots momentum to develop sustainable projects. North American and British peace organizations are over-represented and Muslim majority countries significantly under represented, reflecting a western centricity to the Charter even though penned as an interfaith initiative and based on the principle of the Golden Rule common to all the main religions.

The Charter has attracted peace and non-violence organizations that support the general tenets of the Charter and seek to be compassionate in their mission and bring compassion to the groups and countries they are engaged with. The CfCI does provide valuable peace making resources, which are a useful resource for individuals seeking to demonstrate compassion in their daily lives and among the communities they live and work in. The significance of the Charter appears to be the clarion call to compassion and to challenge individuals to make a difference in their personal lives. As a bottom up approach to peacemaking, conflict resolution, religious tolerance and understanding, the Charter for Compassion in its first ten years has increased in membership and visibility, catching the imagination of tens of thousands of mainly western people. The aspiration of the organisers is enormous in seeking to bring about a change in the thinking and actions of individuals across the world to be the change to create a more equal and just world, where everyone matters and peace, mutual respect and tolerance are default positions.

The difficulties of putting the lofty ambitions of Armstrong and the signatories to the Charter into action become apparent. The scale of ambition extends to establishing and sustaining 'cultures of compassion locally and globally though ... arts, business, education, environment, healthcare, interfaith communities, peace, restorative justice, science and research and women and girls' (Charter for Compassion 2018). CfCI has an Advisory Board of 22 Directors under the leadership of the president Reverend Joan Brown Campbell, with Armstrong as an ex-offcio member, and members drawn from a larger Global Compassion Council, representing many faith positions from around the world. CfC is organised into various teams including the Global Team with Ambassadors for the LGBTQI Community, Business Sector, Women and Girls Sector and the Peace and Restorative Justice Sector, with an additional twenty nine overwhelmingly North American staff members. There are also teams or task forces based in the Asia-Pacific, America, Canada, Pakistan, Australia, United Kingdom, India, and The Netherlands. The scale of the ambition has yet to be realised, there is an appreciable gap 
between what CfCI has set out to accomplish and its actual achievements but a start has been made and focussing on individual capacity to make a difference in creating a more compassionate world will take time.

\section{Conclusion}

In this article, we have traced the emergence of a post-secular world order, as articulated by Jürgen Habermas and others, where religion and religious actors are no longer confined to the private sphere but are able to engage and contribute in the public square. In recent years there has been recognition by western governments of the role religious and interreligious actors can play in peace-making and foreign policy. The resources, infrastructure, esteem, trust and credibility of faith-based organizations can be co-opted by the state and contribute towards the state's soft power. The work of Douglas Johnston and Brian Cox has significantly contributed, along with the encouragement of US President Jimmy Carter and Secretaries of State Madeleine Albright and John Kerry, in persuading US foreign policy makers to engage with faith-based groups and improve religious literacy.

Old secular habits die hard and the involvement of religious actors or progress towards religious literacy has not always been popular or effective. The best of intentions as revealed by Mandaville and Silvestri (2015) can be thwarted by organisational indifference and bureaucratic procedures. Secular actors are nervous and uncomfortable about engaging with religious actors in peace making and assistance giving if they believe that religion is the cause of, or a significant contributor to violence. The claims of advocates of faith-based diplomacy have too often been based on wishful thinking rather than concrete evidence of success achieved demonstrably through faith-based diplomacy. Religious understanding and empathy is dependent upon the good will of participants, which is not always forthcoming particularly where there are multicausal reasons for violence and conflict, each one of which could assume greater significance than religion. Co-opting religion and faith-based actors to pursue national foreign policy interests fools no one and such claims need to be treated with a degree of scepticism.

For Karen Armstrong, what is needed is a more compassionate world, made possible by returning to scriptural exhortations to compassion towards ourselves and others. The Charter for Compassion is intended to encourage a practical outworking of this teaching and has received critical acclaim and the commitment of thousands of supporters to work practically to this end. Armstrong calls for a dramatic change in individual behaviour across the world to spread the message and outworking of acts of compassion. She seeks world change one person at a time, which by its very nature makes the Charter a long-term project.

Armstrong's insistence that it is illegitimate to use sacred texts to justify violence and that instead we should emphasize the Golden Rule is a selective reading of those scriptures. Sacred texts can be used to legitimate both violence and peacemaking and so what is important is the mphassi that is given to certain verses over others. In concentrating on those which emphasises the Golden Rule space can be created for religious actors to promote peace while, at the same time, contextualising violent verses as historically contingent. The peace organizations who have signed up to the Charter and are partners with it have little organizational involvement and have established their own reputation through their ongoing peace and reconciliation work and yet are able to identify with an aspirational movement and benefit from the facilitation of links to resources, individuals and networks.

The Western dominated organisation has developed a strong US-based support and attracted interest and limited engagement across countries across the world, apart from the Muslim majority world, even though Muslims are prominent members of the Global Compassion Council. The organisation is closely identified with Karen Armstrong herself and in order to appeal more broadly would need to develop visible leadership from other faiths and countries.

The Charter has, to date, not initiated significant change in international politics or even peacemaking but has inspired hundreds of thousands of people around the world to engage in its vision. As with other faith-based initiative a heathy scepticism and critique is important but we should not be cynical. CfCI has only just completed its first decade and yet has been able to mobilise hundreds of thousands of people around the world, not least in Karachi, to seek to change their own attitude towards compassion and to seek practical ways to assist others, including in conflict situations. In a world where religious and interreligious initiatives are no longer peripheral then the CfCI serves a valuable role in encouraging 
grassroots initiatives to develop compassion and bring about a more peaceful and tolerant world one person at a time.

\section{References}

Afzal, Madiha. 2015. Education and Atributes in Pakistan: Understanding Perceptions of Terrorism. Washington D.C.: Unites States Institute of Peace.

Agensky, Jonathon. 2017. "Recognizing Religion: Politics, History, and the 'Long 19th Century"”. European Journal of International Relations 12: 1-27.

Albright, Madeleine. 2007. The Mighty and the Almighty: Reflections on America, God, and World Affairs. New York: Harper Perennial.

Annicchino, Pasquale. 2014. "Is the European Union Going Deep on Democracy and Religious Freedom?" The Review of Faith \& International Affairs 12(3): 33-40.

Appleby, R. Scott. 1999. The ambivalence of the sacred: Religion, violence, and reconciliation. New York: Rowman \& Littlefield Publishers.

Appleby, R. Scott. 2003. "Retrieving the Missing Dimension of Statecraft: Religious Faith in the Service of Peacebuilding" in Douglas Johnston ed. Faith-Based Diplomacy: Trumping Realpolitik. Oxford and New York: Oxford University Press pp. 231-58.

Armstrong, Karen. 2011. Twelve Steps to a Compassionate Life. London: Bodley Head.

Armstrong, Karen. 2012. "Practical Compassion: An Interview with Karen Armstrong." Yes Magazine. www.yesmagazine.org/peace-justice/charter-for-compassion-interview-withkaren-armstrong/ [Accessed 28 May 2018].

Armstrong, Karen. 2015. Fields of Blood: Religion and the History of Violence. London: Vintage.

Asad, Talal. 2003. Formations of the Secular: Christianity, Islam, Modernity. Stanford: Stanford University Press.

Bellah, Robert N. 1991. "Between Religion and Social Science", in Robert N. Bellah ed. Beyond Belief: Essays on Religion in a Post-Traditionalist World. Berkeley: University of California Press.

Berger, Peter. 1967. The Sacred Canopy: Elements of a Sociological Theory of Religion. New York: Doubleday.

Berger, Peter. 1999. The Desecularization of the World: Resurgent Religion and World Politics. Grand Rapids: Ethics and Policy Center.

Birdsall, Judd. 2016. "Keep the Faith: How American Diplomacy Got Religion, and How to Keep It". The Review of Faith \& International Affairs 14(2): 110-115

Bruce, Steve. 2002. God is Dead: Secularization in the West. Oxford: Blackwell.

Casanova, Jose. 1994. Public Religions in the Modern World. Chicago: University of Chicago Press.

Casey, Shaun. 2017. "How the State Department Has Sidelined Religion's Role in Diplomacy". Religion and Politics. 5 September. http://religionandpolitics.org/2017/09/05/how-the-statedepartment-has-sidelined-religions-role-in-diplomacy [Accessed 20 May 2018].

Cavanaugh, William T. 2002. "The Myth of the State as Savior" in William T. Cavanaugh ed. Theopolitical Imagination: Discovering the Liturgy as a Political Act in an Age of Global Consumerism. London \& New York: Continuum, pp. 9-52.

Cavanaugh, William T. 2009. The Myth of Religious Violence: Secular Ideology and the Roots of Modern Conflict. Oxford: Oxford University Press.

Ceadel, Martin. 2003. "The Quaker Peace Testimony and its Contribution to the British Peace Movement: An Overview." Quaker Studies 7(1): 9-29.

Cerella, Antonio. 2012. "Religion and political form: Carl Schmitt's genealogy of politics as critique of Jürgen Habermas's post-secular discourse". Review of International Studies, Vol. 38(5): 975-94.

Charter for Compassion. 2009. Charter of Compassion. Available at: https://charterforcompassion.org/charter [Accessed 16 February 2018].

Charter for Compassion. 2018. "About". https://charterforcompassion.org/about1 [Accessed 31 May 2018].

Christiansen, Drew. 2006. "Catholic Peacemaking, 1991-2005: The Legacy of Pope John Paul II". The Review of Faith \& International Affairs 4(2): 21-28. 
Connolly, William E. 1999. Why I Am Not A Secularist. Minneapolis: University of Minnesota Press. Cortright, David. 2008. Peace: A History of Movements and Ideas. Cambridge: Cambridge University Press.

Cox, Brian and Daniel Philpott. 2003. "Faith-Based Diplomacy: An Ancient Idea Newly Emergent". The Brandywine Review of Faith \& International Affairs 1(2): 31-40.

Cox, Brian. 2015. Faith-Based Diplomacy: The Work of the Prophets. Bloomington Ia: Xlibris.

Dallmayr, Fred. 2012. "Post-secularity and (global) politics: a need for radical redefinition". Review of International Studies 38(5): 963-973.

Girard, Rene. 1987. Things Hidden Since the Foundation of the World. Stanford: Stanford University Press.

Girard, Rene. 1996. The Girard Reader. James G. Williams ed. New York: Crossroad Herder.

Girard, Rene. 2013. Violence and the Sacred. London and New York: Bloomsbury.

Gunning, Jerone and Richard Jackson. 2011. "What's so 'religious' about 'religious terrorism'?”. Critical Studies on Terrorism 4(3): 369-388.

Habermas, Jürgen. 2004. "The Pacemaker for Cultural Rights”. Philosophy 79(307): 5-18.

Habermas, Jürgen. 2006. "Religion in the Public Sphere". European Journal of Philosophy 14(1): 125.

Habermas, Jürgen and Joseph Ratzinger. 2007. The Dialectics of Secularization: On Reason and Religion. San Francisco: Ignatius Press.

Habermas, Jürgen. 2008. Between Naturalism and Religion: Philosophical Essays. Cambridge: Polity Press.

Habermas, Jürgen. 2010. "An Awareness of What is Missing” in Jürgen Habermas et al. An Awareness of What is Missing: Faith and Reason in a Post-Secular Age. Cambridge: Polity Press.

Haynes, Jeff. 2009. "Conflict, Conflict Resolution and Peace-Building: The Role of Religion in Mozambique, Nigeria and Cambodia". Commonwealth \& Comparative Politics, 47(1): 52-75.

Hurd, Elizabeth S. 2008. The Politics of Secularism in International Relations. Princeton, NJ: Princeton University Press.

Johnston, Douglas, and Cynthia Samson, eds. 1994. Religion, the Missing Dimension of Statecraft. New York: Oxford University Press.

Johnston, Douglas. ed. 2003. Faith-Based Diplomacy: Trumping Realpolitik. Oxford and New York: Oxford University Press.

Johnston, Douglas and Brian Cox. 2003. "Faith-based Diplomacy and Preventive Engagement" in Douglas Johnston ed. Faith-Based Diplomacy: Trumping Realpolitik. Oxford and New York: Oxford University Press pp. 11-29.

Johnston, Douglas. 2011. Religion, Terror, and Error. Santa Barbara: Praeger

Kerry, John. 2013. "Remarks at the Launch of the Office of Faith-Based Community Initiatives". Washington D.C.: U.S. Department of State. 7 August. https://20092017.state.gov/secretary/remarks/2013/08/212781.htm [Accessed 15 May 2018].

Mandaville, Peter and Sara Silvestri. 2015. Integrating religious engagement into diplomacy: challenges and opportunities. Issues in Governance Studies, 67: 1-13.

Milbank, John. 2006. Theology and Social Theory: Beyond Secular Reason. Oxford: Blackwell.

Norris, Pippa and Ronald Inglehart. 2011. Sacred and Secular: Religion and Politics Worldwide. Cambridge: Cambridge University Press.

Ott, Michael R. 2015. "Translating the Emancipatory Semantics of Religion into the Secular Discourse for a Global, Reconciled Society in the Later Work of Jürgen Habermas". Heathwood Institute and Press. http://www.heathwoodpress.com/wpcontent/uploads/2015/02/Translating-the-Emancipatory-Semantics-of-Religion-.pdf. [Accessed 10 February 2018].

Pabst, Adrian. 2012. "The secularism of post-secularity: religion, realism, and the revival of grand theory in IR". Review of International Studies, 38(5): 995-1017.

Patterson, Eric. 2011. Politics in a Religious World: Building a Religiously Informed U.S. Foreign Policy. London: Continuum. 
Petito, Fabio and Thomas, Scott M. 2015. "Encounter, dialogue, and knowledge: Italy as a special case of religious engagement in foreign policy". The Review of Faith and International Affairs, 13(2): 40-51.

Pope Francis. 2017. "Nonviolence: a Style of Politics for Peace". Message of his Holiness Pope Francis for the Celebration of the Fiftieth World Day of Peace, 1 January. http://w2.vatican.va/content/francesco/en/messages/peace/documents/papa francesco_20161208_messaggio-1-giornata-mondiale-pace-2017.html. [Accessed 12 February 2018].

Rupert, James. 2015. “Teaching Peace in Pakistan's Turbulent Mega-City”. 2 November. https://www.usip.org/publications/2015/11/teaching-peace-pakistans-turbulent-mega-city [Accessed 21 May 2018].

Sacks, Jonathon. 2015. Not in God's Name: Confronting Religious Violence. London: Hodder and Stoughton Ltd.

Simons, Creg and David Westerlund eds. 2016. Religion, Politics and Nation-Building in PostCommunist Countries. London and New York: Routledge.

Smock, David (ed.). 2006. Religious Contributions to Peacemaking: When Religion Brings Peace, Not War. Washington DC: United States Institute of Peace.

Tahir-Ul-Qadri, Muhammad. 2010. Fatwa on Suicide Bombings and Terrorism. London: Minjah-ulQuran International (UK).

Taylor, Charles. 2007. A Secular Age. Harvard: Harvard University Press.

Taylor, Charles. 2009. "The Polysemy of the Secular". Social Research 76(4): 1143-66.

Thomas, Scott M. 2005. The Global Resurgence of Religion and the Transformation of International Relations. New York: Palgrave.

Thomas, Scott M. 2014. "Culture, Religion, and Violence: Rene Girard's Mimetic Theory." Millennium 43(1): 308-327.

Troy, Jodok. 2017. "Two 'Popes' to Speak for the World: The Pope and the United Nations Secretary General in World Politics". The Review of Faith \& International Affairs. 15 (4): 67-78.

Walzer, Michael. 2007. Thinking Politically: Essays in Political Theory. New Haven: Yale University Press.

Wilson, Erin K. 2012. After Secularism: Rethinking Religion in Global Politics. Basingstoke: Palgrave Macmillan.

Yoder, John H. 1983. Christian Attitudes to War, Peace, and Revolution: A Companion to Bainton. Elkhart, In: Mennonite Biblical Seminaries.

Yoder, John H. 1994. The Politics of Jesus. Grand Rapids: Eerdmans. 